\title{
Tinjauan Teodise Dalam Kitab Ayub dan Implikasi Bagi Umat Kristen di Tengah Pandemi COVID-19
}

\author{
Gabriel Dhandi \\ Sekolah Tinggi Teologi Tawangmangu \\ Korespondensi: dhandigabriel91@gmail.com \\ Firman Panjaitan \\ Sekolah Tinggi Teologi Tawangmangu \\ panjaitan.firman@gmail.com
}

\begin{abstract}
The COVID-19 pandemic is an epidemic that is shaking the world today. Its appearance unsettled many people, as many people were affected. Like losing a job, a business goes bankrupt, many lives are lost, some countries are hit by a recession, so suffering is created. From this suffering, there are some people or groups who think that the COVID-19 pandemic arises as a result of human sins and violations against God. By using the literature study method, which departs from compiled data obtained from various books and presented in descriptive form, then the study in this article will discuss the Book of Job which describes the suffering that befell the person Job without cause. The three friends responded to Job's personal suffering as God's punishment for sin. But he was godly men, fearing God, and shunning evil (1:1). The results of the study of the Book of Job showed that the suffering he experienced was not because God had punished Job personally. It is because God has His own purpose for Him. Thus, it can be concluded that the emergence of the COVID-19 pandemic is not the result of human sin.
\end{abstract}

Keywords: covid-19; job; law of retribution; theodicy

\begin{abstract}
Abstrak
Pandemi COVID-19 merupakan sebuah wabah yang mengguncangkan dunia dewasa ini. Kemunculannya membuat resah banyak orang, dimana banyak orang yang terkena dampak. Seperti kehilangan pekerjaan, usaha bangkrut, banyak nyawa yang hilang, beberapa negara terkena resesi, sehingga penderitaan pun tercipta. Dari penderitaan tersebut ada beberapa orang atau kelompok yang beranggapan bahwa pandemi COVID-19 muncul akibat dosa dan pelanggaran manusia terhadap Allah. Dengan menggunakan metode studi literatur, yang berangkat dari kompilasi data yang didapat dari berbagai buku dan disajikan dalam bentuk deskriptif, maka kajian dalam artikel ini akan membahas Kitab Ayub yang menggambarkan tentang penderitaan yang menimpa pribadi Ayub tanpa sebab. Penderitaan yang menimpa pribadi Ayub direspon oleh ketiga temannya sebagai hukuman Allah akibat dosa. Tetapi ia adalah seorang yang saleh, takut akan Tuhan, dan menjauhi kejahatan (1:1). Hasil kajian Kitab Ayub ternyata penderitaan yang dialami bukan karena Allah menghukum pribadi Ayub. Melainkan karena Allah memiliki tujuan-Nya sendiri bagi dirinya. Dengan demikian, dapat disimpulkan bahwa kemunculan pandemi COVID-19 bukan akibat dari dosa manusia.
\end{abstract}

Kata Kunci: covid-19; ayub; penderitaan; hukum retribusi; teodise 


\section{Pendahuluan}

Abad 21 ini muncul sebuah pandemi yang disebut dengan COVID-19 (Corona Virus Disease yang muncul pada tahun 2019), virus ini berasal dari Wuhan, China. ${ }^{1}$ Tanggal 30 Januari 2020, World Health Organization/Organisasi Kesehatan Dunia (WHO) menetapkan Pandemi COVID-19 sebagai Public Health Emergency of International Concern (PHEIC). ${ }^{2}$ Juga, tanggal 12 Februari 2020 WHO juga resmi menetapkan novel coronavirus dengan sebutan Coronavirus Disease (COVID-19). ${ }^{3}$ Sejak kemunculan pandemi ini banyak juga masalah yang muncul, seperti krisis ekonomi, jumlah kematian, dan jumlah kemiskinan meningkat. ${ }^{4}$ Seperti di negara Indonesia. Sejak 2 Maret 2020 pandemi COVID-19 masuk di Indonesia. 13 Oktober 2020 kasus positif pandemi COVID-19 sudah mencapai 340. 662, yang meninggal sudah 12. 027, dan yang sembuh 263. 296. Juga, jumlah kemiskinan meningkat di akhir tahun 2020.5

Dari kasus-kasus yang telah dipaparkan penulis, Rick Wiles, seorang pastor Amerika Serikat mengklaim bahwa pandemi COVID-19 adalah azab Tuhan untuk planet bumi. ${ }^{6}$ Klaim tersebut mengarah kepada konsep hukum retribusi, balas jasa atau ganti ganti rugi, 7 dipertegas lagi seperti: "Jika seorang hidup benar, ia akan makmur; jika ia berdosa, ia akan menderita." 8 Untuk membuktikan pernyataan dari Rick Wiles, penulis tertarik untuk meneropong pandemi COVID-19 menurut kacamata Kitab Ayub. Karena dalam Kitab ini orang yang menderita selalu diarahkan kepada hukuman Allah. Perlu diketahui bahwa Ayub adalah seorang yang saleh (Ay. 1:1), tetapi di masa hidupnya penderitaan menghampirinya, apakah Allah menghukum Ayub? Inti pembahasan Kitab Ayub adalah membahas tentang konsep teodise yang dihadapkan dengan hukum retribusi.

Teodise adalah pembenaran keadilan Allah yang selalu diarahkan pada penderitaan yang terjadi. Sedangkan hukum retribusi adalah sebuah teologi yang menggambarkan bahwa penderitaan yang dialami adalah orang yang dihukum Allah. ${ }^{9}$ Alasan penulis memilih Kitab Ayub karena tokoh Ayub dimunculkan bertujuan untuk mengangkat paham teodise (pembenaran keadilan Allah diatas penderitaan) dan meruntuhkan hukum retribusi pada saat itu, orang benar maka hidupnya makmur dan orang berdosa akan menderita. ${ }^{10}$ Dari kasus diatas penulis ingin membahas tentang teodise dan hukum retribusi dalam kitab Ayub, serta penderitaan yang menimpa Ayub. Penulisakan mengkaji tentang penderitaan bisa menimpa kehidupan orang saleh. Juga, penulis meneliti tentang konsep teodisedan hukum retribusi dalam Kitab Ayub. Setelah itu hasil kajian tersebut akan disandingkan

1Jama, "Presumed Asymptomatic Carrier Transmission of COVID-19," 14 April 2020.

${ }^{2}$ Achmad Yurianto, Pedoman Pencegahan Dan Pengendalian CoronaVirus Disease (COVID-19) (Jakarta: Kementrian Kesehatan RI, 2020), 11.

${ }^{3}$ Tim Kemendagri, Pedoman Umum Menghadapi Pandemi COVID-19: Bagi Pemerintah Daerah Pencegahan, Pengendalian, Diagnosis, Dan Manajemen (JAKARTA: Kementrian Dalam Negeri, 2020), 2.

${ }^{4} \mathrm{Ni}$ Putu Emy Darma Yanti, “Gambaran Pengetahuan Masyarakat Tentang COVID-19 Dan

Perilaku Masyarakat Di Masa Pandemi COVID-19," Jurnal Keperawatan Jiwa 8, no. 2 (2020): 497-498.

5Sherina Anjani Putri, "Pandemi COVID-19 Dalam Sudut Pandang Demogafri Sosial:

Penyebaran, Tantangan, Dampak Sosial Ekonomi Serta Potensi Solusi."

${ }^{6}$ Redaksi WE Online, "Pastor Asal As Klaim CoronaVirus Kiriman Malaikat Maut Dan Azab Tuhan Buat Bumi."

${ }^{7}$ Kalis Stevanus \& Stefanus M. Marbun, "Memaknai Kisah Ayub Sebagai Refleksi Iman Dalam Menghadapi Penderitaan," LOGIA: Jurnal Teologi Pentakosta 1 No. 1 (2019): 10.

${ }^{8}$ Andrew E Hill and John H Walton, Survei Perjanjian Lama (Malang: Gandum Mas, 1996).

${ }^{9}$ Larry J Waters, "Reflections on Suffering from the Book of Job," Evangelical Quarterly 154, no. December (1997): 73-79.

${ }^{10}$ Emanuel Djogo, "Tinjauan Permasalahan Teodise Kitab Ayub Dan Relevansinya Terhadap Penderita HIV/AIDS," Melintas 33, no. 3 (2018): 342-369. 
dengan kasus Pandemi COVID-19. Melalui tulisan ini penulis ingin membuktikan bahwa pandemi COVID-19 muncul bukan akibat dosa manusia dan juga bukan merupakan sebuah hukuman dari Allah. Melainkan memang sudah ada sejak virus-virus lain bermunculan, seperti ebola, influenza, dan virus-virus lainnya. Hanya saja sudah waktunya untuk virus COVID-19 ini mewabah. ${ }^{11}$

\section{Metode Penelitian}

Penelitian ini dilakukan dengan menggunakan studi literatur yang mengkaji konsep teodise dan penderitaan yang terjadi dalam Kitab Ayub. Hasil kajian tersebut disajikan menggunakan metode deskriptif untuk memberikan uraian yang mengarah para pembentukan wawasan kualitatif. ${ }^{12}$ Langkah pertamanya melakukan sebuah pengkajian terhadap konsep teodise, konsep hukum retribusi, dan penderitaan dalam Kitab Ayub dan fungsi teodise jika dihadapkan dengan hukum retibusi dan penderitaan Ayub. Kemudian penulisan ini diarahkan untuk menunjukan relevansinya dengan COVID-19. Bahwa penderitaan yang diakibatkan oleh pandemi COVID-19 bukan merupakan sebuah hukuman dari Allah.

\section{Hasil dan Pembahasan}

Dalam sejarah kehidupan umat manusia, penderitaan selalu ada setiap zamannya. Terutama yang sedang dialami saat ini, dunia sekarang mengalami beragam penderitaan karena dampak dari COVID-19. Penderitaan yang dialami oleh umat manusia saat ini juga pernah terjadi di masa lalu, terutama di zaman Ayub. Yang menjadi permasalahannya adalah dia orang saleh, jujur, takut akan Allah, dan menjauhi kejahatan (Ayb. 1:1), tetapi ia ditimpa kemalangan sehingga mengalami penderitaan yang amat berat (1:12-19; 2:7-8). Dia kehilangan usaha-usaha ternaknya, anak-anaknya meninggal, ditimpa penyakit barah, dan ia ditinggal oleh isterinya. Ini merupakan suatu bencana besar yang datang menimpa kehidupan Ayub sehingga ia pun sangat menderita pada saat itu. Juga, ia pastinya mengalami tekanan batin, depresi, stres, dan lain sebagainya. Yang menjadi pertanyaan saat ini adalah kenapa orang yang saleh, jujur, takut akan Tuhan, dan menjauhi kejahatan bisa ditimpa bencana berat seperti ini. Bukankah hanya orang berdosa saja yang mendapat malapetaka dari Tuhan sebagai hukuman? Apakah Ayub orang berdosa? Bukankah sudah dipertegas kalau Ayub orang saleh, jujur, dan takut akanTuhan?

\section{Latar Belakang Kitab Ayub}

Kitab Ayub merupakan salah satu dari lima Kitab Puisi Perjanjian Lama. Yang di didalamnya ada Kitab Ayub, Mazmur, Amsal, Pengkhotbah, dan Kidung Agung. Kitab Ayub merupakan Kitab Puisi Ibrani yang melestarikan sisa-sisa tradisi hikmat orang Edom.13 Secara tradisional peristiwa-peritiwa yang terjadi di Kitab Ayub di hubungkan dengan masa para bapa leluhur karena gaya hidup dan umur yang panjang (42:16) memiliki kesamaan dengan peristiwa yang terjadi di Kitab Kejadian. ${ }^{14}$ Delitzsch meneliti berdasarkan dari gaya bahasa Kitab, bahwa kitab Ini sezaman dengan Salomo dan pembuangan ke Babel. Artinya penulisan Kitab ini memiliki rentetan waktu yang jauh dengan peristiwa Kitab. Gaya hidup

11 John C. Lennox, Where Is God in a CoronaVirus? Dimana Allah Dalam Dunia Dengan Virus Corona (Surabaya: Literatus Perkantas Jawa Timur, n.d.), 43-44.

12 Sonny Eli Zaluchu, "Strategi Penelitian Kualitatif Dan Kuantitatif Di Dalam Penelitian

Agama," Evangelikal: Jurnal Teologi Injili dan Pembinaan Warga Jemaat 4, no. 1 (2020): 28.

${ }^{13}$ Hill and Walton, Survei Perjanjian Lama.

14 Ibid. 
orang yang kaya diukur dengan banyaknya ternakdan Ayub memiliki umur panjang sama seperti para bapa leluhur Israel di Kitab Kejadian (42:16).

Ayub hidup pada zaman kuno, pastinya masyarakat setempat dalam lingkungannya Ayub memiliki cara berpikir atau konsep berpikir kuno juga. Salah satu konsep yang ada di dalam kehidupan masyarakat zaman Ayub adalah konsep hukum retribusi." Jika seorang hidup benar, ia akan makmur; jika ia berdosa, ia akan menderita." Hukum retribusi menjadi konsep umum di masyarakat zaman Ayub (Ay. 4:7;Kej. 38:7). Hal ini terlihat jelas saat Ayub merespon penderitaan yang ia alami, dia mempertanyakan kenapa ia menderita, kenapa Tuhan diam saja. Sehingga ia melontarkan sebuah klausa "Allah telah berlaku tidak adil terhadap aku" (19:6), karena ia merasa telah menempuh hidupnya dengan baik. ${ }^{15}$

Kitab Ayub merupakan sebuah Kitab yang memakai konsep teodise untuk menentang paham retribusi. Kitab ini ditulis dengan tujuan untuk menentang dan meruntuhkan paham retribusi yang kuno, di mana kitab Ayub menunjukan sebuah kisah seorangsaleh ditimpa penderitaan. ${ }^{16}$ Selanjutnya, teman-temanmenuduhnya bahwa penderitaan yang ia alami merupakan sebuah hukuman atau kutukan karena ia berdosa (Ayb. 4, 5, 8, 11, 15, 18, 20, 22, 25).

\section{Pribadi Ayub}

Ayub adalah seorang laki-laki yang tinggal ditanah Us dan ia adalah orang yang saleh, jujur, takut akan Allah, dan menjauhi kejahatan (Ay. 1:1). Ia juga memiliki tujuh anak laki-laki dan tiga anak perempuan. Ia juga memiliki ternak kambing domba berjumlah tujuh ribu ekor, tiga ribu ekor unta, lima ratus pasang lembu, lima ratus kedelai betina, dan memiliki budak dengan jumlah yang banyak. Dimana Ayub adalah orang terkaya di timur pada waktu itu. Anak-anaknya biasa mengadakan pesta dirumah mereka dan mengundang saudara-saudaranya untuk datang pesta bersama. Jika sesudah pesta Ayub menguduskan mereka dengan mempersembahkan korban bakaran sesuai dengan jumlah mereka. Ayub senantiasa hidup saleh setiap harinya, jika ia dan keluarganya melakukan pelanggaran maka ia menguduskan diri dengan mempersembahkan korban bakaran. Ia adalah seorang yang saleh dan benar dimata Tuhan.

\section{Asal Muasal Penderitaan Ayub}

Muncul sebuah pertanyaan kenapa penderitaan bisa menimpa kehidupan Ayub? Padahal ia adalah seorang yang saleh, jika melakukan kesalahan ia selalu menguduskan diri dengan mempersempahkan korban bakaran kepada Allah. Sejak diawal Kitab Ayub, iblis tampil sebagai kreator terhadap penderitaan yang Ayub alami. Juga, pokok pikiran Kitab Ayub yakni membuktikan perkataan iblis bahwa penderitaan dapat memudarkan kesalehan Ayub kepada Allah. ${ }^{17}$ Jika mengkaji isi Kitab Ayub, maka akan ditemukan nasari dalam ayat 1:6-12 dan 2:1-6. Kedua bagian ayat-ayat tersebut menunjukan percakapan antara Allah dan Iblis. Pertama, bagian pasal 1:6:12 menunjukan sebuah pertemuan antara anak-anak Allah dengan Tuhan, salah satu diantara anak Allah itu adalah Iblis. ${ }^{18}$ Dalam ayat 7 diperlihatkan

${ }^{15}$ Kalis Stevanus \& Stefanus M. Marbun, “Memaknai Kisah Ayub Sebagai Refleksi Iman Dalam Menghadapi Penderitaan."

16R. Potter, A New Catholic Commentary On Holy Scripture - Job, ed. Thomas Nelson (Wesmonasteri: United State America, 1975), 417.

${ }_{17}$ Frans Paillin Rumbi, "Babak Akhir Penderitaan, Dosa, Dan Teodice Dalam Epilog Kitab Ayub 42:7-17," Veritas Lux Mea (Jurnal Teologi dan Pendidikan Kristen) 1, no. 2 (2019): 53-64, https://jurnal.sttkn.ac.id/index.php/Veritas/article/view/43.

18 Pertemuan anak-anak Allah juga dapat disebut sebagai "perkumpulan" atau bisa juga disebut sebagai sidang ilahi, lih. Marthin Steven Lumingkewas, El Dan Yahweh Allah Israel (Yogyakarta: Diandra Kreatif, n.d.), 31. 
awal dari percakapan antara Allah dengan Iblis. Awal percakanapan tersebut diawali dengan pertanyaan dari Allah: "Dari mana engkau?" Iblis menjawab: "Dari mengelilingi dan menjelajahi bumi." Pertanyaan Allah yang kedua mengarahkan perhatian kepada Ayub: "Apakah engkau melihat hambaku Ayub?" Dilanjutkan dengan penyataan: "Sebab tiada seorangpun seperti dia, yang saleh, jujur, yang takut akan Allah, dan menjauhi kejahatan." Lalu Iblis menanggapi penyataan Allah tersebut: "Apakah dengan tidak mendapat apa-apa Ayub takut akan Allah?" Dilanjutkan dengan pertanyaan lagi: "Bukankah Engkau membuat pagar sekeliling dia dan rumahnya serta segala yang dimilikinya?" Lagi dilanjutkan dengan pernyataan: "Apa yang telah dikerjakannya telah Kauberkati dan apa yang dimilikinya makin bertambah di negeri itu. Tetapi ulurkanlah tangan-Mu dan jamahlah segala yang dipunyainya, ia pasti mengutuki Engkau di hadapan-Mu." Setelah Iblis mengemukakan pendapatnya, Allah menjawabnya: "Nah, segala yang dipunyainya ada dalam kuasamu; hanya janganlah engkau mengulurkan tanganmu terhadap dirinya."

Setelah percakapan Allah dengan Iblis selesai, maka Iblis pun melakukan apa yang Allah suruh. Segala bencana pun menimpa Ayub, dimana lembu sapi dan keledai-keledai betinanya diserang dan dirampas oleh orang-orang Syeba (1:14). Lalu bencana lain adalah kambing domba dan para penjaganya habis disambar oleh api yang datang dari langit (1:16). Unta-untanya juga dirampas oleh orang-orang Kasdim dengan tiga pasukan (1:17). Bukan hanya itu, anak-anak laki-laki dan perempuannya juga habis mati karena angin ribut bertiup dari seberang padang gurun dan menyerang rumah dimana anak-anaknya berpesta.

Setelah segala bencana tersebut menimpa kehidupan Ayub, tidak didapati kalau ia menghujat Allah. Malah ia memuji dan menyembah Tuhan dengan kata-kata: "TUHAN yang memberi, TUHAN yang mengambil, terpujilah nama TUHAN." Semua harta benda, usaha ternak, dan anak-anaknya laki-laki maupun perempuan diambil oleh Iblis atas perintah TUHAN. Dengan tujuan untuk menguji seberapa setia dan seberapa kenal Ayub kepada Allah yang ia sembah dan hasilnya ia tetap setia kepada Allah.

Kedua, dipertemuan antara anak-anak Allah dengan Tuhan yang kedua dan salah satu anak Allah tersebut ada juga Iblis. Disitu diperlihatkan Allah memulai percakapan dengan cara yang sama seperti percakapan yang pertama, yaitu dengan melemparkan pertanyaan kepada Iblis: "Dari mana engkau?" Iblis juga menjawab dengan jawaban yang sama: "Dari perjalanan mengelilingi dan menjelajahi bumi." Lalu Allah mengeluarkan penyataan dengan kalimat yang sama seperti penyataan di percakapan yang pertama (1:8; band 2:3). Namun, ada kalimat tambahan baru: "ia tetap tekun dalam kesalehannya, meskipun engkau telah membujuk aku melawan dia untuk mencelakakannya tanpa alasan." Kalimat yang dikeluarkan Allah kepada Iblis tersebut ditujukan ke Ayub, dimana kalimat tersebut adalah kalimat pujian-Nya terhadap orang yang setia kepada Dia. Iblis pun menanggapi pujian Allah yang diberikan kepada Ayub tersebut: “Kulit ganti kulit!" (Hukum Lex Talionis)19 “Orang akan memberikan segala yang dipunyainya ganti nyawanya. Tetapi ulurkanlah tanganmu dan jamahlah tulang dan dagingnya, ia pasti mengutuki Engkau di hadapan-Mu." Lalu Tuhan menanggapi pernyataan Iblis tersebut: "Nah, ia dalam kuasamu, hanya sayangkan nyawanya." Kalimat: "hanya janganlah engkau mengulurkan tanganmu terhadap dirinya" dengan kalimat: "hanya sayangkan nyawanya" memiliki persamaan maksud, yaitu jangan bunuh Ayub. Setelah percakapan kedua tersebut selesai, Iblis pergi dari hadapan Tuhan dan langsung menimpakan Ayub dengan penyakit barah yang busuk dari telapak kakinya sampai ke batu

${ }^{19}$ Lex Talionis adalah hukum pembalasan seperti istilah mata ganti mata, gigi ganti gigi, atau kulit ganti kulit. Pengertian umumnya adalah suatu hukum yang dapat dimintakan pembalasan terhadap orang yang bersalah dan dapat dituntut dengan penderitaan yang setimpal, lih. Roy B. Zuck, Biblical Theology of The Old Testament (MALANG: GANDUM MAS, 2005), 87. 
kepalanya. ${ }^{20}$ Disitulah Ayub mulai berkabung karena bencana yang menimpa hidupnya. Istrinya menyuruh Ayub mengutuki Allah karena ia kehilangan semua harta benda bahkan anak-anaknya. Bencana yang menimpa Ayub akibat percakapan kedua antara Allah dan Iblis, tidak juga membuatnya menghujat Allah bahkan ia tidak berdosa sama sekali.

\section{Hukum Retribusi}

Hukum atau doktrin retribusi adalah hukum reward dan punishment, dimana Allahlah yang menjadi pemberi reward dan pemberi punishment tersebut. Jika seseorang tersebut benar maka ia menerima reward dari Allah, jika seseorang tidak benar maka ia menerima punishment dari Allah. Doktrin atau hukum retribusi memiliki beberapa karakteristik. ${ }^{21}$ Pertama, Dewa kuno, lebih khusus lagi Dewa-Dewa di zaman Semit kuno merupakan adalah dewa suku, tanpa terkecuali Yahweh. Ia adalah penegak tatanan sosial dan pembalas dari sentimen seorang masyarakat yang marah kepada sesamanya. Hukum ini berfungsi untuk kemakmuran rakyat secara keseluruhan, bukan unit-unit tertentu. Jika tatanan sosial masyarakat tersebut dilanggar secara sembarang, maka Dewa atau Yahweh yang ikut campur, yang menjadi agen penimpa kemalangan kepada pelaku yang melanggar. Konteks pelanggaran ini adalah pelanggar supranatural, yang melanggar tatanan sosial religius, sepuluh perintah Allah. Kedua, pada masa pra-profetik, Yahweh tidak hanya memberi hukuman kepada orang yang melanggar moralitas masyarakat. Tetapi ia juga memberi hukuman kepada orang yang melanggar peraturan yang ia buat, pemberi itu dibuat secara ringkas, yang dinamakan sebagai doktrin pembalasan Ilahi. Dimana Allah mengasihi mereka yang takut akan Dia. Para pemazmur mengatakan bahwa Tuhan adalah Allah yang menghukum setiap penghinaan yang dilakukan terhadap Dia.

Ketiga, hukum retribusi merupakan sebuah doktrin yang ditujukan hanya kepada individual saja, tidak kepada komunitas maupun masyarakat secara menyeluruh. Keempat, metode doktrin retribusi merupakan konsep pembalasan murni di zaman kuno. Reward dan punishment terbatas hanya pada kehidupan duniawi, seperti kenikmatan dan penderitaan di bumi. Awal dari konsep reward dan punushiment ini adalah kejatuhan manusia dalam dosa yang tercatat dalam Kitab Kejadian 3:1-24. Karena disitu telah dijelaskan secara gamblang penyebab penderitaan manusia. Setelah manusia jatuh ke dalam dosa, Allah menubuatkan penderitaan yang akan menimpa manusia. ${ }^{22}$ Perempuan akan menderita disaat ia melahirkan dan laki-laki menderita ketika ia mencari rezeki. Dalam Perjanjian Lama, salah satu pandangan poluler adalah "penderitaan sebagai akibat dari dosa". Tanpa dosa maka tidak ada penderitaan, andaikata manusia tidak berdosa mereka tidak akan menderita. Musa juga mengingatkan bangsa Israel agar mereka tidak berbuat dosa, supaya mereka terhindar dari penderitaan (Im. 26:1-46; Ul. 28:1; 30:15-20). Lama-kelamaan pun terbentuk sebuah konsep bahwa orang benar akan hidup sejahtera dan orang fasik akan menderita (Mzm. 1:16; Ams. 4:18-19; Yer. 17:5-8), sehingga pemazmur pun menyinggung akan hal ini (Mzm. 37:1-

${ }^{20}$ Barah adalah suatu penyakit menular, dari hewan ternak, domba, kambing, dan kuda. Penyakit barah ini muncul disebabkan oleh bakteri yang berbentuk batang yang membentuk suatu spora. Sehingga spora ini dapat menular atau terjangkit ke manusia sehingga menimbulkan luka seperti bisul, yaitu benjolan dipermukaan kulit yang berisi nanah. Barah ini dinamakan pustula ganas, lih.J. I. Packer, Ensiklopedia Fakta Alkitab: Bible Almanac 2, ed. Merrill C. Tenney dan Willian White. Jr (Malang: Yayasan Penerbit Gandum Mas, 2001), 974.

${ }^{21}$ C. G. Montefiore, “The Doctrine of Divine Retribution in the Old Testament, and the Rabbinical Literature," The Jewish Quartely Review 3. No. 1 (1980): 2-3.

22 P. Hendrik Njiolah, Misteri Penderitaan Manusia (Yogyakarta: Yayasan Pustaka Nusatama, 2008), 13. 
40). Sehingga disimpulkan bahwa segala bencana, penyakit, penderitaan, dan segala konsekuensinya adalah hukuman akibat dosa. ${ }^{23}$

Dari penjelasan di atas, penulis dapat menyimpulkan bahwa hukum retribusi tersebut juga Allah gunakan untuk memberi punishment dan reward kepada umat-Nya secara supranatural, bisa juga secara material. Allah memberi punishment kepada orang yang melanggar perintah dan memberi reward kepada orang yang takut akan Dia. Namun konsep tersebut tidak imbang, karena lebih banyak mengarah kepada material. Pemikiran yang hanya mengarah kepada hal material, fisik, atau kepada sesuatu yang berbenda merupakan konsep murni masyarakat kuno. ${ }^{24}$ Termasuk masyarakat kuno pada zaman Ayub. Dimana kemakmuran dan penderitaan seseorang di dunia menjadi tolak ukur masyarakat kuno dalam menilai orang tersebut berdosa atau tidak.

\section{Retribusi Dalam Kitab Ayub}

Jika dikaitkan dalam Kitab Ayub, masyarakat dalam konteks ini memegang teguh doktrin atau hukum retribusi. Bagi penulis ketiga teman Ayub yang datang untuk menjenguk keadaannya sudah cukup untuk mewakili masyarakat yang lain. Ketiga temannya tersebut bernama Elifas orang Teman, Bildad orang Suah, dan Zofar orang Naama. Dalam percakapannya dengan Ayub, bahwa diperlihatkan mereka mempertahankan bahwa penderitaan merupakan akibat dari dosa. Oleh karena itu mereka melihat bahwa penderitaan yang Ayub alami merupakan penderitaan yang berakar dari dosa (4-27). ${ }^{25}$

\section{Ketiga Teman Ayub Berpendapat Tentang Penderitaan Ayub}

Ketiga teman Ayub tersebut bukan merupakan orang dari golongan bawah, melainkan orang berpengaruh dan orang-orang terpandang. Karena saat ketiga temannya melakukan interaksi percakapan, mereka berlandaskan dengan pemahaman-pemahaman tertentu. Pertama, dalam mengutarakan pemikirannya kepada Ayub, Elifas berlandaskan dengan sebuah pengalaman penglihatannya dan implikasi moral dari kelemahan umat manusia. ${ }^{26}$ Dimana inti dari setiap ucapannya saat pembicaraan sesi pertama (4-5), kedua (15), dan ketiga (22) memperlihatkan bahwa sengsara itu senantiasa datang kepada manusia akibat dosa (4:8-21, 5:1-7). Bahkan pembicaraan Elifas yang ketiga memperlihatkan kepada para pembaca kalau secara terang-tetangan Elifas mencela Ayub sebagai seorang manusia munafik (22:15). Kedua, Elifas mengutarakan perkataannya berlandaskan pengalaman. Beda dengan Bildad, ia berdasarkan tradisi atau adat istiadat (8:8-10; 18). Ayat 5-6 membuktikan kalau Bildad menilai sesuatu berdasarkan apa yang ia lihat.27 Perkataan-pertakaan Bildad berisi dalil-dalil adat istiadat saat ia memarahi Ayub (ay. 5-21). Perkataan-perkataan Bildad mengarah pada keyakinan bahwa hanya orang berdosa sajalah yang ditimpa penderitaan. Secara tegas ia mengklaim bahwa Ayub adalah orang berdosa. ${ }^{28}$ Ketiga, pada pasal 11:2-3 Zofar naik darah dengan setiap penyangkalan Ayub. Pandangan Zofar terhadap penderitaan Ayub hanya berlandaskan pada patok dugaan belaka. Karena Zofar hanya berpendapat dari

${ }^{23}$ Surip Stanislaus, Tragedi Kemanusiaan (Yogyakarta: Kanisius, 2008), 55.

${ }^{24}$ Djogo, “Tinjauan Permasalahan Teodise Kitab Ayub Dan Relevansinya Terhadap Penderita HIV/AIDS," 245.

${ }^{25}$ Firman Panjaitan, "Allah Yang Kreatif Dan Dinamis Dalam Ayub 42: 7-17: Sebuah

Perlawanan Terhadap Teologi Retribusi," Kurios: Jurnal Teologi dan Pendidikan Agama Kristen 6, no. 2 (2020): 240-254.

${ }^{26}$ Carol A. Newsom, The Book Of Job: Introduction, Commentary, and Reflection (Nashville: Abingdon Press, 1996), 376.

${ }^{27}$ Carol A. Newsom, The Book Of Job: Introduction, Commentary, and Reflection.

${ }^{28}$ Ibid. 
apa yang dia lihat dari keadaan Ayub, dia berpegang pada doktrin atau hukum retribusi. Pasal 11 terdapat tuduhan-tuduhan yang dilontarkan kepada Ayub seperti Ayub banyak bicara (ay. 2), sombong dan congkak (ay. 3-4), pendosa (ay. 5-6), membenarkan perbuatanperbuatan Allah (ay. 7-10), dan menganjurkan untuk Ayub bertobat jika tidak maka ia akan mati (ay. 13-20). Tuduhan-tuduhan tersebut belum tentu benarnya.

Setelah ketiga temanya tersebut berbicara, ia menanggapi setiap perkataan yang dilontarkan kepadanya. Dimana ia menanggapi tuduhan-tuhan tersebut dengan sumpah resmi, "Demi Allah yang hidup" ( Ayb. 27:2: bdk. Rut 3:13; I Sam. 14:45, 25:34; II Sam. 14:11; I Raj. 17:1, 12, 18:10; II Raj. 5:20; II Taw. 18:13). Ayub membela dirinya dengan menekankan ketidaksalahannya terhadap Allah. Karena tuduhan-tuduhan yang diberikan kepadanya dengan menekankan kalau penderitaan yang ia alami adalah akibat dari dosa. Ketiga temannya tersebut menuduh bahwa Ayub itu orang berdosa dan menyuruh ia untuk bertobat terhadap dosa yang diperbuat. Karena tuduhan-tuduhan tersebut ia menjadi kesal kepada teman-temannya. Akibat dari kekesalan tersebut ia menyalahkan Allah atas penderitaan yang menimpanya (Ayb 27:2-4). Ayat 5 dan 6, Ayub tetap mempertahankan kalau ia tidak bersalah terhadap Allah dan menganggap bahwa teman-temannya telah memberi kesaksian palsu dan mereka juga akan ditimpa kemalangan seperti orang fasik $(27: 7)$.

\section{Konsep Teodise Dalam Kitab Ayub}

Kata Teodise berasal dari bahasa Yunani, yaitu Theos (Allah)dan Dike (keadilan, pembenaran, dan kebenaran), ditarik ke bahasa Inggris yaitu Theodicy. Kata Teodise memiliki beberapa pengertian, yaitu ilmu yang berusaha membenarkan Allah dalam pandangan manusia, usaha untuk mempertahankan keadilan Allah dalam membiarkan suatu bencana atau penderitaan manusia terjadi, dan usaha membuat kemahakuasaan Allah tetap sesuai dengan eksistensi kejahatan atau bencana. ${ }^{29}$ Syafieh mengatakan bahwa dalam membahas tentang ketuhanan, teodise dapat menyimpulkan tentang Tuhan dengan mempresentasikannya. Teodise juga dapat mempresentasikan Tuhan dengan wujud presonal atau dengan sebutan Allah Abraham, Ishak, dan Yakub. Teodise juga bersifat filosofis dalam membahas masalah tentang ketuhanan dan lebih mempertimbangkan aspek objektivitas serta terbuka secara umum. ${ }^{30}$ Secara tegas menyatakan secara orientasi pembahasan teodise tentang wujud Tuhan hanya berangkat dari aspek eksistensialitas-Nya. ${ }^{31}$ Maksudnya bahwa pembahasan hanya diarahkan pada sejauh mana keberadaan Tuhan yang bisa ditangkap oleh akal pikiran dengan mempertimbangkan data tentang ketuhanan yang konkret.

Dapat disimpulkan bahwa teodise adalah pemahaman tentang keadilan Allah atau sebuah paham yang membenarkan seluruh tindakan Allah di alam semesta. Juga, membahas tentang keberadaan Allah yang dapat ditangkap oleh pikiran manusia. Contoh seperti membahas sosok Allah sebagai pribadi yang berentitas, penampakan Allah, tangan Allah, dan wujud Allah. Teodise mulai nampak dalam Kitab Ayub dimulai dari kehadiran temannya yang lain yang bernama Elihu.

\section{Elihu Berpendapat tentang Penderitaan Ayub}

Marie-Claire dan Barth-Frommel ${ }^{32}$ mengatakan bahwa Elihu adalah seorang berhikmat dari angkatan muda, orang Us, dari kaum Raama. Ia adalah seorang guru

${ }^{29}$ Lorens Bagus, Kamus Filsafat (JAKARTA: Gramedia Pustaka Utama, 1996), 825-826.

${ }^{30}$ Syafieh M, "Teodise Dan Agama."

${ }^{31}$ Louis Berkhof, Sistematic Theology (U.S.A: Eermands Publishing, 1981), 43.

${ }^{32}$ Marie-Claire \& Barth Frommel, Ayub: Bergumul Dengan Penderitaan, Bergumul Dengan Allah, ed. Gabo Gea (Jakarta: BPK Gunung Mulia, 2016), 116-117. 
sekaligus sebagai pengantar pertemuannya dengan Allah. Ia juga seorang yang memiliki tata krama yang baik, analisis yang cermat dan pemberani. Ia berpendapat dengan panjang lebar tentang penderitaan yang menimpa Ayub. Dari peristiwa Allah menghukum teman-teman Ayub, hanya Elihu yang tidak dihukum. Ia lolos dari hukuman Allah, berarti secara implisit ia memiliki pengenalan yang benar akan Allah. Hal ini diperkuat oleh pendapat Elihu bahwa Ayub berbicara tanpa pengetahuan $(34: 35,35: 16)$. Nama Elihu ini menjadi pro-kontra para ahli, Nichols ${ }^{33}$ dalam bukunya "The Composition of the Elihu Speeches" mencatat 40 ahli menduga bahwa tokoh Elihu tidak termasuk dalam naskah asli Kitab Ayub. Dimana 40 ahli tersebut berpendapat bahwa Elihu merupakan tokoh sisipan oleh pengarang lain yang dilakukan kemudian. Karena pandangan ini diajukan terdapat perbedaan gaya bahasa dengan dialog ketiga sahabat Ayub. Juga, tidak dicantumkan nama Elihu dalam penghukuman Allah kepada sahabat Ayub. Nichols juga mencatat ada 27 ahli yang yakin bahwa tokoh Elihu adalah bagian dari naskah asli. Dari 27 ahli berpendapat, jika Elihu dan pendapatnya dihilangkan dari Kitab Ayub, maka makna seluruh Kitab Ayub juga akan hilang bersama-sama. Para ahli juga sepakat kalau pendapat Elihu itu cocok ditempatkan sebagai jembatan antara percakapan antara Ayub dan ketiga temannya dengan jawaban Allah.

Sebenarnya Elihu ingin menekankan bahwa orang baik atau orang saleh cenderung pada kesombongan, dimana mereka suka dipuji, dan merasa bahwa dirinya yang paling benar. Melalui penderitaan ini Allah dapat mengajarkan Ayub melalui kesengsaraan dan penderitaan, mereka harus merenungkan jalan hidupnya dan menyadari kerendahan mereka dihadapan Allah yang lebih tinggi. ${ }^{34}$ Dapat dikatakan bahwa pembicaraan Elihu (3237) kepada Ayub untuk menemui Allah.

Dari percakapan antara Ayub dengan ketiga temannya, Ayub selalu merespon dan menanggapi setiap pembicaan mengenai penderitaan yang menimpa dirinya dengan berdebat kepada ketiga sahabatnya. ${ }^{35}$ Ayub tidak terima dengan tuduhan-tuduhan yang dilontarkan ketiga temannya terhadap dia. Tetapi, saat Elihu berpendapat ia tidak merespon atau tidak menjawab. Elifas, Bildad, dan Zofar berpendapat dan yakin bahwa penderitaan yang Ayub alami merupakan akibat dari ia melakukan kejahatan ata dosa terhadap Allah. Oleh sebab itu Ayub selalu menanggapi setiap pendapat yang dikeluarkan oleh ketiga temannya ini. Ayub tersinggung dan sakit hati terhadap tuduhan yang diberikan kepadanya. Ia membela diri dan meminta agar Allah sebagai Pencipta menyatakan keadialan dengan mengatakan bahwa Ayub adalah seorang yang benar dimata Tuhan.

\section{Respon Allah Terhadap Keluh Kesah Ayub}

Elihu mengajar Ayub untuk berbicara tentang Allah dengan memakai pengertian dan pengetahuan. Ayub juga tidak merespon apa yang telah disampaikan Elihu kepadanya. Setelah itu, Allah merespon keluh kesah Ayub atas penderitaan yang ia alami, disinilah puncak dari peran teodise dalam Kitab Ayub. Beberapa dari respon Allah sudah menunjukan peran teodise, dimana diperlihatkan Allah menampakan diri-Nya saat Ayub menderita. Pertama, Allah datang menemui Ayub dan Ia berdiri ditengah badai. Ia berdiri di tengah badai dengan tujuan untuk menyatakan kuasanya, kewibawaan-Nya, dan melindungi manusia dari kemuliaan yang tak tertahankan. Allah memperkenalkan diri sebagai Pencipta dan Pemelihara umat manusia. Penampakan Allah di hadapan Ayub di harapkan akan membenarkan dan menunjukan belas kasihannya kepada hamba yang menderita tanpa alasan.

\footnotetext{
33Jacob Soesilo, "Misteri Ayub Dan Temannya Elihu," 2014.

${ }^{34}$ Marie-Claire \& Barth Frommel, Ayub: Bergumul Dengan Penderitaan, Bergumul Dengan Allah.

${ }^{35}$ Rumbi, “Babak Akhir Penderitaan, Dosa, Dan Teodice Dalam Epilog Kitab Ayub 42:7-17."
} 
Penampakan Allah ini sering menimbulkan kesan bahwa Allah merendahkan Ayub sebagai ciptaan yang tidak berarti. Hal ini bertujuan untuk menyadarkan bahwa Ayub tidak seharusnya menuntut keadilan kepada Allah. Ia tidak memahami rencana Allah, ia memahami Allah sebagai Hakim yang melihat segala langkah manusia dan membenarkan orang yang tidak bersalah, menghukum orang yang bersalah. Di situlah letak kebingungan Ayub, di mana ia terikat dengan Allah yang tidak lagi dipahaminya. Karena ia melihat bahwa Allah tidak bertindak dengan apa yang dipahaminya. Dimana dalam penampakan di tengah badai, Allah tidak membenarkan tindakakan Ayub yang menuntut keadilan. Melainkan Allah ingin menunjukan bahwa ia adalah Pencipta dan Pemelihara dunia. Allah memperkenalkan seluruh Karya Ciptaan-Nya dengan memberikan pertanyaan-pertanyaan yang tidak bisa dijawab Ayub. Ia membuat pertanyaan dengan pertanyaan retorika. Inti dari pertanyaan-pertanyaan retorika tersebut adalah tentang penciptaan bumi (38:4-7) ciptaan laut (38:8-11), penciptaan fajar $(38: 12,14,15)$, tentang luasnya laut dan bumi? (38:16-20), pertanyaan tentang dari mana datangnya air? (38:22-27). Lagi Allah menggunakan pertanyaan retorika untuk menyadarkan Ayub seperti, siapa yang menentukan gugusan bintang dan awan (38:31-36)?36

Bukan hanya menggunakan pertanyaan retorika tentang alam semesta Allah menunjukan kemahakuasaan-Nya, tetapi juga tentang semua binatang yang dikenal dalam Perjanjian Lama. Pasal 39:1-32 diperlihatkan bahwa Allah memperhatikan binatang-binatang dan mengetahui segala sesuatu yang terjadi pada semua binatang. Seperti mengetahui tentang kelaparan anak-anak singa, kambing gunung, rusa melahirkan, memperhatikan keledai liar, lembu hutan (mirip kerbau), burung unta, tentang kuda, dan burung terbang. Gambaran tentang hewan-hewan itu telah lazim dan dipakai oleh pengarang untuk menyadarkan orang-orang pada masa itu. ${ }^{37}$

Setelah Allah memakai pertanyaan retorika untuk memperlihatkan kemahakuasaanNya kepada Ayub, pengarang Kitab Ayub memperlihatkan sesi tanya jawab antara Ayub dan Allah. Setelah Allah menjawab tentang keluh kesah Ayub, ia merespon semua pertanyaan retorik yang Allah berikan. Jawaban Ayub yang pertama terdapat pada Pasal 39:34-38 diperlihatkan bahwa disaat Ayub berhadapan dengan Allah, ia terlihat hina dan rendah karena keterbatasannya sebagai manusia. Dimana Ayub tidak mengetahui kenapa penderitaan tiba-tiba menimpanya tanpa sebab. Ungkapan Ayub "Mulutku kututup dengan tangan" itu secara implisit ia mengakui bahwa ia berbicara tanpa pengetahuan. Karena ia sendiri mengakui bahwa masih ada pikiran dan pertanyaan yang belum ia pahami. Ia mulai menyadari bahwa betapa luas pengetahuan yang belum dipahami tentang Allah. Dari jawaban Allah terhadap keluh kesah Ayub tersebut ia mulai menyadarinya, dimana sebelum Allah menjawab ia menuntut akan keadilan Allah terhadap dirinya. Karena ia menderita tanpa sebab. Tapi setelah Allah menjawab semua keluh kesahnya ia mulai menyadari bahwa ia tidak harus menuntut akan keadilan dari Allah. Karena ia menyadari bahwa jika dibandingkan dengan Allah Sang Pencipta, ia merasa tidak layak.

Kedua, Allah kembali lagi menjawab keluh kesah Ayub dengan menampakan diriNya ditengah badai. Jawaban Allah tersebut hampir sama dengan jawaban yang pertama. Tapi jawaban Allah tersebut menunjukan bahwa Ia memisahkan dirinya dengan Ayub. Saat Ayub menuntut keadilan kepada Allah, ia secara implisit menunjukan kalau Allah yang salah akan penderitaan yang menimpanya. Dari tuntutan Ayub tersebut menunjukan bahwa ia sebenarnya lupa pada dirinya sendiri kalau ia adalah hanya seorang makhluk ciptaan dan mengindikasikan kepada kesombongan sehingga ia menentang Allah.

\footnotetext{
${ }^{36}$ Firman Panjaitan, "Analisis Pertanyaan Retorika Dalam Ayub," in Teologi Kitab Ayub, ed. Pniel Maiaweng (Makassar: STFT Jaffray, 2019), 90-102.

${ }^{37}$ Marie-Claire \& Barth Frommel, Ayub: Bergumul Dengan Penderitaan, Bergumul Dengan Allah.
} 
Pengarang Kitab Ayub memperlihatkan bahwa Allah ingin menunjukan kalau manusia itu tidak dapat menghapus penderitaan dan kejahatan di dunia ini. Ia hanya dapat mengatasi kesombongannya sendiri yang tidak terima ditimpa oleh penderitaan. Manusia pun tidak dapat melawan kuasa kesombongan yang terdapat di dunia ini, yaitu makhluk ciptaan Allah: Behemot (Kuda Nil) dan Lewiatan (Buaya), mereka adalah makhluk mitis. ${ }^{38}$

Behemot nama ini berbentuk jamak, yaitu kehormatan, dari kata Ibrani yang berarti "binatang dan menunjukan kebesaran dan kekuatan." Ia mewakili kekuatan yang besar dan tidak dikendalikan oleh pengertian. Orang yang menghadapi di tempat dan waktu yang salah dapat dibinasakan tanpa alasan, sama seperti peristiwa orang kecelakaan yang tidak tahu kapan dan dimana. Kuda nil adalah ciptaan Allah, ia makan rumput seperti lembu. Kuasanya mengagumkan, otot, alat kelamin, tubuh, tulang, dan segalanya kuat tiada bandingannya. Sungai Nil yang tiap tahun banjir tidak dapat mengganggunya. Ia di buat sebagai binatang pertama seperti manusia pertama dalam mite kuno.

Selain Behemot sebagai makhluk mitis, ada juga Lewiatan. Ia amat berbahaya dan merusak, membunuh orang dan meruntuhkan karya mereka. Ia menjadi lambang segala kuasa yang tidak dapat manusia jinakan, seperti gempa bumi, tsunami, kemarau panjang, wabah penyakit, dan sebagainya. Di seluruh Dunia Timur Dekat Kuno Lewiatan memainkan peran penting dalam cerita dan gambar (41:1-8). Walaupun di buru, buaya tidak dapat dijinakan dan siapa yang memegang dia akan melawan sampai tidak bisa dipegang lagi. Pengarang Kitab Ayub memakai lambang mite seperti Behemot dan Lewiatan. Sedangkan penulis memakai bencana alam seperti tsunami, gempa bumi, banjir bandang, kemarau panjang, letusan gunung, banjir, wabah penyakit, dan bencana alam lainnya. Dalam hal ini pengarang Kitab Ayub ingin menunjukan bahwa manusia tidak bisa melawan dan menghapuskan penderitaan di dunia. Manusia tidak bisa menyombongkan dirinya hanya karena ia merasa saleh dan dekat dengan Allah. Melainkan yang dapat manusia lakukan adalah melawan kesombongannya sendiri dan hanya tetap berpegang pada kekuatan yang Tuhan berikan.

Jawaban Ayub yang kedua ini terdapat pada pasal 42:1-6. Dimana jawabannya yang kedua ini menegaskan jawabannya yang pertama. Jawaban yang kedua ini menjadi kunci konsep teodise yang berperan mempertahankan kemahakuasaan Allah melalui pertemuan antara Ayub dengan Dia. Jawaban Ayub yang kedua terdapat pada ayat kedua sampai Ayat keenam. Ayat 2 menunjukan kalau Ayub mengakui kemahakuasaan Allah, yang sebelumnya ia menuntut keadilan kepada Allah. Ayat 3 dan 4 ia mengakui bahwa dirinya berbicara tentang Allah tanpa pengertian dan ia tidak mengetahui rencana ilahi dari Allah. Ayat 5 ia mengakui bahwa dia hanya mendengar dari orang saja tentang Allah, seperti pemahaman hukum retribusi dari masyarakat sekitarnya, oraang-orang berhikmat dan percakapan orang-orang berilmu pada saat itu. Tetapi setelah pertemuannya dengan Allah ia mengetahui sendiri tentang Tuhan yang sebenarnya. Ayat keenam menunjukan bahwa ia menyesal dan menarik kembali setiap perkataan-perkataannya tentang Allah, yaitu tuntutan tentang keadilan Allah. Dimana sebelumnya ia mempertahankan kebenarannya sendiri di hadapan ketiga temannya. Ia menolak kritikan dari mereka yang semakin keras terhadap dia. Tetapi setelah pertemuannya dengan Allah, ia menyadari bahwa dengan tuntutannya tersebut membahayakan hubungannya dengan Allah, ia membuka dirinya, ia menerima Tuhan sebagai Allahnya, dan berbalik kepada Allah.

Dari jawaban Allah yang pertama dan kedua tersebut sudah menunjukan bahwa hukum retribusi sudah diruntuhkan oleh konsep teodise. Pemahaman orang yang menderita karena dosa sudah diruntuhkan oleh kehadiran Allah kepada Ayub. Baik itu bencana Allah, wabah penyakit, dan bencana-bencana lain yang diderita oleh manusia itu bukanlah serta

${ }^{38}$ Ibid. 
merta dari dosa atau pelanggaran terhadap perintah Tuhan. Melainkan penderitaan yang diderita tersebut memiliki tujuan dari Tuhan. Seperti pribadi Ayub, ia merupakan orang yang dekat dengan Tuhan, ia takut akan Allah dan menjauhi kejahatan (1:1), tetapi ia tidak menyadari kesalahan dalam dirinya. Yaitu, kesombongan. Dimana ia merasa berhak menuntut keadilan dari Allah dan merasa berhak komplain terhadap penderitaan yang menimpanya karena ia sudah saleh hidupnya.

\section{Ayub Berdamai Dengan Ketiga Temannya dan Dengan Allah}

Sebenarnya maksud dari ketiga teman Ayub itu baik, dengan hikmat mereka ingin mengajak Ayub untuk memulihkan hubungannya dengan Allah. Tetapi mereka bertolak dari peranggapan bahwa setiap orang yang menderita telah melakukan pelanggaran terhadap hukum Tuhan dan berdosa. Dimana mereka berbicara seakan-akan mereka berada di tahkta Allah, mereka berbicara sesuai dengan doktrin yang mereka anut, yaitu doktrin retribusi. Dimana mereka juga tidak perlu mendengarkan pembelaan Ayub karena mereka sudah menganggap Ayub bersalah dan berdosa (42:7). Allah meminta mereka untuk memberikan korban penghapusan dosa (42:8). Setelah berdamai dengan ketiga temannya, keadaannya pun dipulihkan oleh Allah (42:10-17) dan penderitaan yang Ayub alami bukanlah akibat dosa. Melainkan, untuk menunjukan kesombongan yang ada didalam diri Ayub.

\section{Implikasi}

Dunia dewasa ini sedang menghadapi kasus pandemi COVID-19. Karena kemunculan pandemi ini banyak sekali dampak-dampak yang dialami oleh seluruh umat manusia. Dimana banyak orang yang mati, kehilangan pekerjaan karena PHK (Putus Hubungan Kerja), banyak perusahaan yang tutup, perekonomian di tiap negara menurun drastis, dan dampak-dampak yang lainnya. Oleh karena dampak-dampak tersebut, penderitaan terjadi bagi umat manusia. Karena yang dulunya punya pekerjaan menjadi tidak memiliki pekerjaan, yang miskin menjadi makin miskin, mencukupi kebutuhan pokok menjadi semakin susah, dan masih banyak yang lainnya. Bukankah dampak-dampak seperti itu merukapan penderitaan? Bagi penulis itu merupakan suatu penderitaan yang dialami oleh setiap orang. Tetapi apakah pandemi COVID-19 merupakan sebuah hukuman karena dosa manusia? Jika dilihat dari kacamata Kitab Ayub bahwa pandemi COVID-19 bukan muncul akibat dari dosa. Karena tidak semua orang di dunia itu adalah orang yang berdosa, dalam arti sering melanggar aturan Tuhan maupun moral masyarakat. Memang banyak orang-orang yang masih melanggar moral, hukum agama, dan perintah Tuhan yang ada di Alkitab, tetapi juga tidak sedikit orang saleh. Penulis juga memiliki bukti yang kuat tentang pandemi COVID-19 itu bukan merupakan hukuman dari Allah akibat dosa manusia. Penulis akan mengangkat natur dari virus, karena pandemi COVID-19 merupakan bagian dari virus.

Bagi penulis mengangkat natur dari virus diperlukan, karena untuk memperkuat bukti bahwa virus COVID-19 tidak muncul akibat dosa manusia. ${ }^{39}$ Peter Pollard mengatakan bahwa virus memiliki 100 juta tipe, keberadaannya sangat penting bagi kelangsungan hidup manusia. Pertumbuhan bakteri dan infeksi virus itulah yang menjaga ekosistem tetap berfungsi hingga saat ini. Virus mengambil peran yang sangat penting bagi perputaran nutrisi di bumi. Virus adalah pahlawan terkecil tanpa tanda jasa bagi kehidupan umat manusia.Marilyn Roossinck mengatakan bahwa hanya ada 1\% dari virus berbahaya bagi

39 Oktavianus Klido Wekin Eugenius Ervan Sardono, Nikodemus Hermiawan, “Makna Fenomena Kematian Massal Di Tengah Pandemi Covid-19 Berdasarkan Refleksi Dari Ayub 1: 1-22," Visio Dei: Jurnal Teologi KRisten 2, no. 2 (2020): 265-283. 
target inangnya. Dimana hanya $1 \%$ virus berbahaya dari $100 \%$ populasi virus di dunia dan salah satu populasi virus dari 1\% itu adalah pandemi COVID-19.

John C. Lennox Mengutip artikel dari seorang geologis yang bernama Peter Ward dan ahli astronomi yang bernama Donald Brownlee yang terdapat dalam buku Rare Earth, dimana bagian babnya berjudul "Manfaat Tak Terduga dari Lempeng Tektonik." Dimana tertulis argumen bahwa kepunahan dari segala bentuk bisa terjadi jika lempeng tektonik itu berhenti bergerak. Dimana menurut argumen tersebut lempeng tektonik sangat penting bagi pembentukan benua dan keseimbangan antara daratan dan lautan dapat terpelihara. Juga, lempeng tektonik juga menjaga medan magnetik bumi, yang berfungsi melindungi bumi dari pancaran kosmik yang dapat berakibat buruk bagi kehidupan seluruh makhluk hidup. Jadi kesimpulan antara kedua ahli ini adalah bisa saja lempeng tektonik menjadi syarat utama terjadinya kehidupan di bumi dan merupakan merupakan keharusan dari keberadaan lempeng tektonik ini demi menjaga dunia agar tetap memiliki pasokan air. ${ }^{40}$

Pandemi COVID-19 maupun gempa bumi merupakan komponen penting bagi terjadinya kehidupan seluruh makhluk hidup di muka bumi. Maka dari itu, penulis menyimpulkan bahwa pandemi COVID-19 muncul bukan merupakan hukuman atau kutukan Allah akibat dosa manusia, melainkan sudah ada. Hanya saja virus ini belum mewabah ke manusia, tetapi kepada binatang-binatang seperti kelelawar, tikus bambu, unta, dan musang. ${ }^{41}$ Awalnya, virus ini menyebar dari hewan ke manusia, lalu mewabah dari manusia ke manusia. ${ }^{42}$ Lalu virus yang berbahaya itu menempel pada sel target atau inang (entah itu manusia atau binatang) sehingga membahayakan sel target yang sudah ditargetkan. Demikan pula dengan pandemi COVID-19 ini yang menempel pada sel yang ditargetkan sehingga banyak korban yang berjatuhan dan mati karena terkena serangannya. Tidak peduli siapa orangnya, apa statusnya, dari mana asalnya, dan saleh atau tidak orangnya, jika memang sudah menjadi sel target bagi pandemi COVID-19 untuk menempel, maka yang harus dilakukan adalah hanya mencegah penyebaran dari sel-sel berbahaya tersebut. Jelas bahwa kemunculan pandemi COVID-19 bukan akibat dari dosa, melainkan karena sudah waktunya pandemi ini muncul di dunia.

Apa yang seharusnya dilakukan oleh setiap orang yang terkena dampak dari pandemi COVID-19 ini. Penulis mengangkat beberapa poin yang berdasarkan Kitab Ayub. Pertama, saling menolong satu sama lain. Seperti memberi sembako kepada orang-orang yang terkena dampak pandemi ini. Karena banyak orang-orang yang tidak bisa bekerja, yang kehilangan pekerjaan, dan akhirnya sulit untuk mencukupi kebutuhan primer mereka. Berkaca dari penderitaan yang Ayub alami, tidak seorangpun yang membantunya, malah orang-orang sekitar mengklaim bahwa ia telah dihukum karena dosa. Sama halnya pada masa kini, penderitaan yang dialami karena COVID-19 membuat orang beranggapan bahwa itu akibat dari dosa. Padahal Kristus telah menebus seluruh dosa umat manusia di atas kayu salib, artinya manusia menderita bukan karena dosa, karena sudah ditebus dengan penderitaan Kristus. ${ }^{43}$ Semua penderitaan yang dialami manusia (termasuk akibat COVID19) adalah rancangan Allah. Manusia tidak perlu mempertanyakan alasannya, pastinya

40John C. Lennox, Where Is God in a CoronaVirus? Dimana Allah Dalam Dunia Dengan Virus Corona, 43-44.

${ }^{41}$ Y Yuliana, "Corona Virus Diseases (Covid-19): Sebuah Tinjauan Literatur," Wellness And Healthy Magazine 2, no. 1 (2020): 187-192.

${ }^{42}$ Ray Faradillahisari N Moch Halim Syukur, Bayu Kurniadi, Haris, "Penanganan Pelayanan Kesehatan Di Masa Pandemi Covid-19 Dalam Perspektif Hukum Kesehatan," Journal Inicio Legis Volume 1 Nomor 1 Oktober 2020 1, no. 1 (2020): 1-17.

${ }^{43}$ Darrow L. Miller, Membangun Bangsa Dengan Pikiran Allah (Jakarta: YPPM, 2000), 188. 
Allah merancang untuk kebaikan dunia. ${ }^{44}$ Kedua, membenahi diri sebagai manusia ciptaan. Selama hidup, apakah manusia hidup sudah selayaknya manusia? Yang tidak menyombongkan diri hanya karena sudah mendapatkan apa yang diinginkan? Yang tidak menganggap diri-Nya paling benar dan seakan-akan menyamakan posisi dengan Pencipta? Hal ini perlu dilakukan oleh setiap manusia. Seperti Ayub, dia merasa dirinya saleh, takut akan Tuhan dan menjauhi kejahatan. Tiba dia ditimpa penderitaan, ia merasa berhak menuntut keadilan dari Allah. Ketiga, selalu berpegang pada kuasa Tuhan. Karena hanya Dia yang memegang kendali tentang apa yang sedang terjadi di dunia dewasa ini. Dia sudah memperhitungkan semuanya dan memiliki tujuan-Nya sendiri yang tidak di mengerti oleh umat manusia.

\section{Kesimpulan}

Sebagai umat manusia ciptaan Allah yang sedang mengalami penderitaan akibat pandemi COVID-19. Sebagai seorang Kristen yang menjadi pengikut Kristus, yang diperintahkan untuk menjadi garam dan terang bagi dunia. Disinilah saatnya untuk menampilkan citra Kristus bagi lingkungan dimana kita berada. Berdasarkan kacamata Kitab Ayub dalam melihat keadaan dunia sekarang. Sebagai orang Kristen mari untuk tidak memandang kemunculan pandemi COVID-19 ini sebagai hukuman dari Allah akibat dosa manusia. Sebaliknya sebagai orang Kristen penulis mengajak setiap orang percaya untuk membenahi diri masing-masing. Apakah orang percaya sudah hidup selayaknya pengikut Kristus? Yang memperhatikan dan peduli kepada orang-orang sekitar walaupun bukan orang percaya? Seperti Yesus Kristus yang telah memperhatikan orang-orang miskin dan menaruh belas kasihan kepada mereka. Penulis juga mengajak setiap orang percaya untuk tidak menyombongkan diri disaat mendapat persolan dalam hidup dan harus tetap mengandalkan kekuatan dan hikmat dari Tuhan.

\section{Rujukan}

Achmad Yurianto. Pedoman Pencegahan Dan Pengendalian CoronaVirus Disease (COVID-19). Jakarta: Kementrian Kesehatan RI, 2020.

Bagus, Lorens. Kamus Filsafat. JAKARTA: Gramedia Pustaka Utama, 1996.

C. G. Montefiore. "The Doctrine of Divine Retribution in the Old Testament, and the Rabbinical Literature." The Jewish Quartely Review 3. No. 1 (1980): 1-51.

Carol A. Newsom. The Book Of Job: Introduction, Commentary, and Reflection. Nashville: Abingdon Press, 1996.

Djogo, Emanuel. “Tinjauan Permasalahan Teodise Kitab Ayub Dan Relevansinya Terhadap Penderita HIV/AIDS." Melintas 33, no. 3 (2018): 342-369.

Eugenius Ervan Sardono, Nikodemus Hermiawan, Oktavianus Klido Wekin. "Makna Fenomena Kematian Massal Di Tengah Pandemi Covid-19 Berdasarkan Refleksi Dari Ayub 1: 1-22." Visio Dei: Jurnal Teologi KRisten 2, no. 2 (2020): 265-283.

Hill, Andrew E, and John H Walton. Survei Perjanjian Lama. Malang: Gandum Mas, 1996.

J. I. Packer. Ensiklopedia Fakta Alkitab: Bible Almanac 2. Edited by Merrill C. Tenney dan Willian White. Jr. Malang: Yayasan Penerbit Gandum Mas, 2001.

Jacob Soesilo. “Misteri Ayub Dan Temannya Elihu.” 2014.

Jama. "Presumed Asymptomatic Carrier Transmission of COVID-19." 14 April 2020.

John C. Lennox. Where Is God in a CoronaVirus? Dimana Allah Dalam Dunia Dengan Virus Corona. Surabaya: Literatus Perkantas Jawa Timur, n.d.

Kalis Stevanus \& Stefanus M. Marbun. “Memaknai Kisah Ayub Sebagai Refleksi Iman

${ }^{44}$ Sonny Zaluchu, "Penderitaan Kristus Sebagai Wujud Solidaritas Allah Kepada Manusia,"

DUNAMIS: Jurnal Penelitian Teologi dan Pendidikan Kristiani 2, no. 1 (2017): 61. 
Dalam Menghadapi Penderitaan." LOGIA: Jurnal Teologi Pentakosta 1 No. 1 (2019).

Louis Berkhof. Sistematic Theology. U.S.A: Eermands Publishing, 1981.

Marie-Claire \& Barth Frommel. Ayub: Bergumul Dengan Penderitaan, Bergumul Dengan Allah. Edited by Gabo Gea. Jakarta: BPK Gunung Mulia, 2016.

Marthin Steven Lumingkewas. El Dan Yahweh Allah Israel. Yogyakarta: Diandra Kreatif, n.d. Miller, Darrow L. Membangun Bangsa Dengan Pikiran Allah. Jakarta: YPPM, 2000.

Moch Halim Syukur, Bayu Kurniadi, Haris, Ray Faradillahisari N. "Penanganan Pelayanan Kesehatan Di Masa Pandemi Covid-19 Dalam Perspektif Hukum Kesehatan." Journal Inicio Legis Volume 1 Nomor 1 Oktober 2020 1, no. 1 (2020): 1-17.

Ni Putu Emy Darma Yanti. “Gambaran Pengetahuan Masyarakat Tentang COVID-19 Dan Perilaku Masyarakat Di Masa Pandemi COVID-19." Jurnal Keperawatan Jiwa 8, no. 2 (2020): 497-498.

Njiolah, P. Hendrik. Misteri Penderitaan Manusia. Yogyakarta: Yayasan Pustaka Nusatama, 2008.

Panjaitan, Firman. "Allah Yang Kreatif Dan Dinamis Dalam Ayub 42: 7-17: Sebuah Perlawanan Terhadap Teologi Retribusi." Kurios: Jurnal Teologi dan Pendidikan Agama Kristen 6, no. 2 (2020): 240-254.

- - - "Analisis Pertanyaan Retorika Dalam Ayub." In Teologi Kitab Ayub, edited by Pniel Maiaweng, 90-102. Makassar: STFT Jaffray, 2019.

R. Potter. A New Catholic Commentary On Holy Scripture - Job. Edited by Thomas Nelson. Wesmonasteri: United State America, 1975.

Redaksi WE Online. "Pastor Asal As Klaim CoronaVirus Kiriman Malaikat Maut Dan Azab Tuhan Buat Bumi."

Roy B. Zuck. Biblical Theology of The Old Testament. MALANG: GANDUM MAS, 2005.

Rumbi, Frans Paillin. "Babak Akhir Penderitaan, Dosa, Dan Teodice Dalam Epilog Kitab Ayub 42:7-17." Veritas Lux Mea (Jurnal Teologi dan Pendidikan Kristen) 1, no. 2 (2019): 53-64. https://jurnal.sttkn.ac.id/index.php/Veritas/article/view/43.

Sherina Anjani Putri. "Pandemi COVID-19 Dalam Sudut Pandang Demogafri Sosial: Penyebaran, Tantangan, Dampak Sosial Ekonomi Serta Potensi Solusi."

Stanislaus, Surip. Tragedi Kemanusiaan. Yogyakarta: Kanisius, 2008.

Syafieh M. “Teodise Dan Agama."

Tim Kemendagri. Pedoman Umum Menghadapi Pandemi COVID-19: Bagi Pemerintah Daerah Pencegahan, Pengendalian, Diagnosis, Dan Manajemen. JAKARTA: Kementrian Dalam Negeri, 2020.

Waters, Larry J. "Reflections on Suffering from the Book of Job." Evangelical Quarterly 154, no. December (1997): 73-79.

Yuliana, Y. "Corona Virus Diseases (Covid-19): Sebuah Tinjauan Literatur." Wellness And Healthy Magazine 2, no. 1 (2020): 187-192.

Zaluchu, Sonny. "Penderitaan Kristus Sebagai Wujud Solidaritas Allah Kepada Manusia." DUNAMIS: Jurnal Penelitian Teologi dan Pendidikan Kristiani 2, no. 1 (2017): 61.

Zaluchu, Sonny Eli. "Strategi Penelitian Kualitatif Dan Kuantitatif Di Dalam Penelitian Agama." Evangelikal: Jurnal Teologi Injili dan Pembinaan Warga Jemaat 4, no. 1 (2020): 28. 